Click www.researchjournal.co.in/online/subdetail.html to purchase.

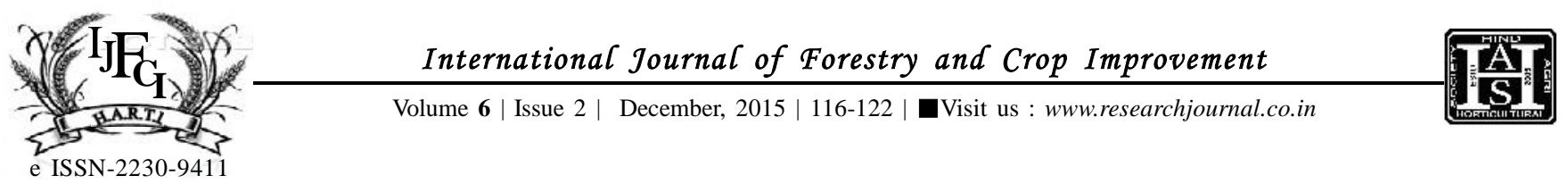

\title{
Effect of seasoning on sprouting of stem cutting and their survival in threatened medicinal important plant, Commiphora wightii (Arn.) Bhan.
}

\author{
R.N. KuLlOLI, SURESH KuMAR, S.K. JindAL and MANJIT SinGH
}

\begin{abstract}
Commiphora wightii (Arn.) Bhan. known as Indian bdellium is a large shrub of family Burseraceae. Its oleo-gum resin is known to be anti-inflammatory, antirheumatic, hypocholesterolmic, hypolipidemic, and antifertility agent. In order to extract more oleo-gum resin it has been overtapped in past, killing its natural populations thus prompting IUCN to keep it in 'Data Deficient category'. Its $e x$-situ conservation through seed as well as vegetative propagation has met with variable success. Seasoning of stem cuttings for a duration that ensures more sprouting and consequent survival was, therefore, aim of this study. Cut stem cuttings kept for $0,1,2,3,4$ and 5 days and treated with IBA $(5000 \mathrm{ppm})$ revealed that maximum root biomass $(0.56 \mathrm{~g})$, maximum number of shoots $(6)$ and length of shoots $(49.50 \mathrm{~cm})$ was found in five days seasoned stem cuttings. After 27 months of plantation maximum survival was found in four and five days seasoned stem cuttings (50\% each) cuttings. Collar diameter (1.75 $\mathrm{cm}$ ) was maximum in five day seasoned stem cuttings. Maximum plant height $(119.75 \mathrm{~cm})$ was in four days seasoned cuttings followed by five days seasoned cuttings $(96 \mathrm{~cm})$. Thus, four to five days of seasoning in the month of August emerged most optimum for sprouting of stem cuttings and their subsequent survival in field plantation.
\end{abstract}

KEY WORDS : Commiphora wightii, Collar diameter, IUCN, Survival, Seasoning

How TO CITE THIS ARTICLE : Kulloli, R.N., Kumar, Suresh, Jindal, S.K. and Singh, Manjit (2015). Effect of seasoning on sprouting of stem cutting and their survival in threatened medicinal important plant, Commiphora wightii (Arn.) Bhan. Internat. J. Forestry \& Crop Improv., 6 (2) :116-122.

Article ChronicAL : Received : 10.09.2015; Revised : 13.11.2015; Accepted : 25.11.2015

MEMBERS OF RESEARCH FORUM

Address of the Correspondence : R.N. KULLOLI, Central Arid Zone Research

Institute, JODHPUR (RAJASTHAN) INDIA Email: r.kulloli@gmail.com

Address of the Coopted Authors : SURESH KUMAR, Division of Integrated Land Use Management and Farming Systems, Central Arid Zone Research Institute, JODHPUR (RAJASTHAN) INDIA $\_-\ldots \ldots \ldots$ Email: sk_ecology@yahoo.co.in

S.K. JINDAL, Division of Plant Improvement Propagation and Pest Management Plant Genetics Division, Central Arid Zone Research Institute, JODHPUR (RAJASTHAN) INDIA Email: jindal53@yahoo.co.in

$\overline{\text { MANJIT SINGH, Directorate of Mushroom Research, Chambaghat, SOLAN (H.P.) INDIA }}$ Email: directordmr@gmail.com 